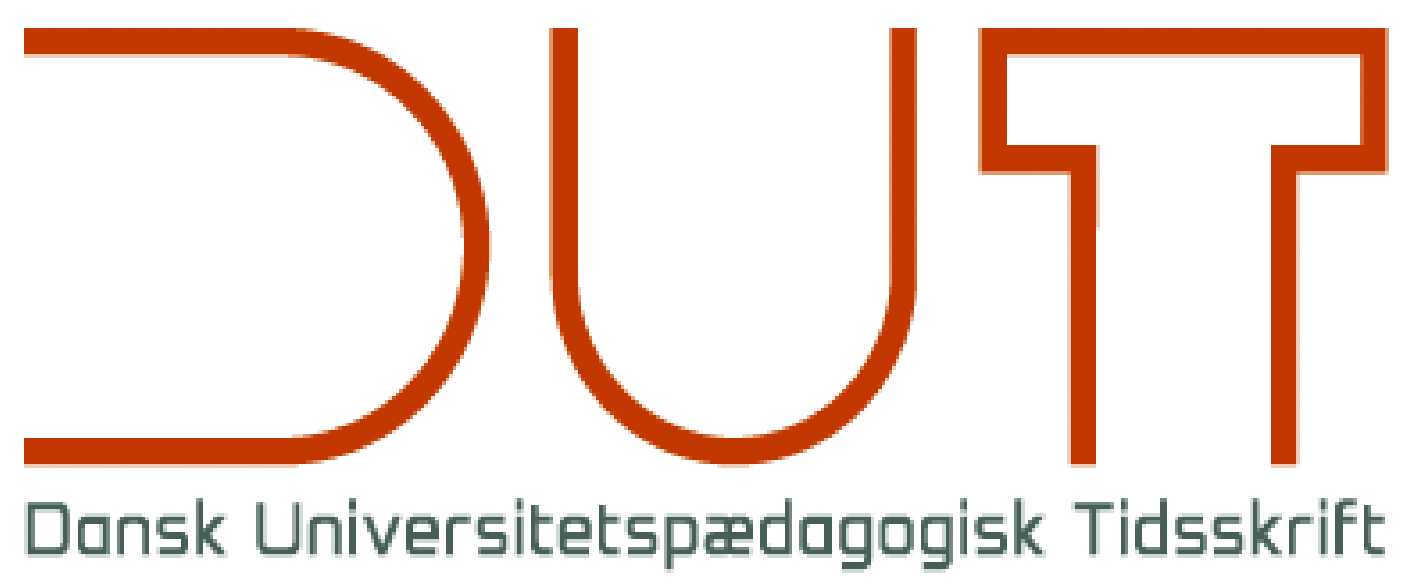

Læringsrum

Årgang 14 nr. 27 / 2019

Titel

Kollektiv Akademisk Vejledning - Fra forskning til praksis

Forfattere

Sidetal

Thomas Viskum Gjelstrup Bredahl

197-199

Udgivet af

Dansk Universitetspædagogisk Netværk, DUN

URL

> http://dun-net.dk/

Betingelser for brug af denne artikel

두 Copyright
Denne artikel er omfattet af ophavsretsloven, og der må citeres fra den. Følgende betingelser skal dog være opfyldt:

- Citatet skal være i overensstemmelse med "god skik"

- Der må kun citeres „i det omfang, som betinges af formålet“

- Ophavsmanden til teksten skal krediteres, og kilden skal angives ift. ovenstående bibliografiske oplysninger.

DUT og artiklens forfatter 


\title{
Kollektiv Akademisk Vejledning - Fra forskning til praksis
}

\author{
Skrevet af Helle Merete Nordentoft, Helle Hvass, Kristina Mariager-Anderson, Søren Smede- \\ gaard Bengtsen, Anne Smedegaard, Sarah Damgaard Warrer
}

Udgivet i 2019 på Aarhus Universitetsforlag, 124 sider ISBN: 9788771847628

Anmeldt af Thomas Viskum Gjelstrup Bredah|a,1

anstitut for Idræt og Biomekanik, Syddansk Universitet

De fleste ansatte varetager det at skulle vejlede opgaver i et akademisk miljø som en del af deres almindelige opgaver. Én til én-vejledning har været den mest almindelige måde at guide den studerende hen imod at aflevere færdige opgaver af kvalitet. Dog har akademiske institutioner været nødt til at omtænke organiseringen af vejledningssituationen, blandt andet på grund af økonomiske og organisatoriske forandringer. Herunder der gennemføres kollektiv akademisk vejledning i stedet for den mere klassiske én til én-vejledning.

Bogen "Kollektiv Akademisk Vejledning - Fra forskning til praksis" gør op med tankerne om, at kollektiv akademisk vejledning udelukkende er en økonomisk nødløsning eller et billigere alternativ til én til én-vejledning. Med udgangspunkt i relevante studier argumenterer bogen for potentialerne ved kollektiv akademisk vejledning og inspirerer til videre arbejde med vejledningsformen. Med udgangspunkt i både teoretiske afsæt, men i særdeleshed også praktiske afsæt, giver bogen gode argumenter for at anvende kollektiv vejledning og giver på samme tid praktiske anvisninger til, hvordan det kan gøres.

Bogen er opbygget i fire centrale dele. Del 1 omhandler de studerendes perspektiv. Del 2 afklarer, hvad kollektiv akademisk vejledning er. Del 3 diskuterer udfordringerne ved den kollektive akademiske vejledning, og del 4 præsenterer et inspirationskatalog med fire forskellige temaer.

Nedenstående gennemgås kort, hvad de enkelte dele i bogen omhandler.

\section{DEL 1: De studerendes perspektiv. S. 13-17}

Bogen starter med et kapitel, der præsenterer de studerendes perspektiver på og kritiske tilgang til kollektiv vejledning. Kapitlet præsenterer relevant viden, og særligt argumentet om kollektiv vejledning som en spareøvelse giver et godt afsætsgrundlag til videre at diskutere potentialet af den kollektive akademiske vejledning. Kapitlet indeholder gode perspektiver fra de studerende men det er dog ret kort, og jeg kunne godt have ønsket mig, at de studerendes perspektiver var blevet udfoldet endnu mere.

\section{DEL 2: Hvad er kollektiv akademisk vejledning? S. 17-38}

I del 2 giver forfatterne en grundig introduktion til, hvad kollektiv akademisk vejledning kan være, og hvordan det kan organiseres. Grundlæggende problematikker eller forventninger fra de studerende samt vejlederen præsenteres og sættes i relation til den kollektive vejled-

\footnotetext{
${ }^{1}$ Kontakt: tbredahl@health.sdu.dk
} 
ning. Det fungerer godt, at der løbende i kapitlet præsenteres konkrete eksempler på, hvordan den kollektive akademiske vejledning kan organiseres, og hvilke forhold vejlederen før, under og efter skal være særligt opmærksom på. Forfatterne bidrager igennem hele afsnittet med eksempler på hjælpemidler og litteratur, som kan støtte vejledningen. Der er flere gode bud på e-læringsrelaterede platforme og metoder, som kan hjælpe de studerendes refleksion samt accept og udbytte af den kollektive vejledning.

\section{DEL 3: Udfordringer i kollektiv akademisk vejledning. S. 39-51}

Del 3 i bogen opridser centrale udfordringer for såvel vejledere som den studerende. Der præsenteres relevante problemstillinger, og forfatterne diskuterer forskellige måder at undgå udfordringerne eller løse disse, inden de bliver problematiske for læringen hos de studerende.

Afslutningsvis præsenterer kapitlet nogle ganske fine anbefalinger til arbejdet med kollektiv akademisk vejledning og konkrete handlinger, der er mulige at implementere uafhængigt af akademisk kontekst.

DEL 4: Inspirationskatalog. S. 55 - 120

Del $4 \mathrm{i}$ bogen er opbygget som et inspirationskatalog med 4 forskellige temaer.

\section{Tema 1: Introduktion til kollektiv akademisk vejledning}

Under tema 1 præsenterer forfatterne relevante, vedkommende og introducerende eksempler på og øvelser til, hvordan man kan introducere de studerende til kollektiv akademisk vejledning. Temaet præsenterer også gode eksempler på, hvordan der kan skabes struktur og klarhed over vejledningsprocessen ved at illustrere konkrete eksempler på planer over vejledningsforløb.

\section{Tema 2: Hvordan kan peersamarbejde praktiseres?}

Tema 2 er et meget praktisk og anbefalende kapitel. Jeg synes, at de helt konkrete forslag til, hvordan de studerende kan give hinanden feedback, og hvordan der kan etableres regler $\mathrm{i}$ gruppen, er relevante og brugbare. Kapitlet er meget "hands-on" og er via de eksempler, der gives, godt egnet som inspirationskatalog til egen vejledning og til at sikre en hensigtsmæssig og målrettet dialog imellem de studerende.

\section{Tema 3: Hvordan kan akademiske processer faciliteres?}

De praktiske råd og forslag til, hvordan der kan arbejdes med akademiske processer, fortsætter i dette kapitel. Forfatterne bidrager med mange eksempler på tekst, som kan forklare de studerende, hvad de enkelte delelementer af en eksamensopgave består af. Det er gode eksempler, som selvfølgelig skal omskrives lidt, hvis det skal anvendes i andre faglige kontekster. Det havde dog været ønskværdigt, hvis forfatterne i øget grad havde fokuseret mere på, hvordan de akademiske processer på en god måde kunne faciliteres i selve den kollektive akademiske vejledning.

\section{Tema 4: Hvordan kan vejledningens kvalitet undersøges?}

Bogens sidste kapitel indeholder gode praktiske forslag til øvelser, hvor både de studerende men også vejlederen kan blive klogere på, hvorvidt den kollektive akademiske vejledning har haft den ønskede effekt på de studerendes læring. Desuden kan de øvelser, der præsenteres, 
hjælpe vejlederen til at få indsigt i, hvilke elementer der skal fokuseres yderligere på i det videre forløb.

\section{God hjælp til arbejdet med kollektiv akademisk vejledning}

Generelt er bogen en god hjælp til at komme i gang med kollektiv akademisk vejledning. Til os, der har arbejdet med kollektiv vejledning over noget tid, er der bestemt også gode råd og inspirerende arbejdsformer at hente. Jeg kunne godt have ønsket mig, at de teoretiske elementer relateret til kollektiv akademisk vejledning, der bliver præsenteret i de første 3 kapitler, havde fået lov til at fylde lidt mere. Der er god læring at hente, og det ville jeg gerne have haft mere af. Til gengæld leverer forfatterne en lang liste af supplerende litteratur, som giver mulighed for selv at indhente den viden, som ikke uddybes i bogen.

Hvis du er interesseret i vejledning generelt eller konkret står overfor udfordringen at skulle gennemføre kollektiv akademisk vejledning, vil jeg bestemt anbefale bogen. 